\title{
The Threat of a Rising Sea Level: Saving Statehood through the Adoption of Uti Possidetis Juris
}

\author{
Kelvin Mbatia *
}

\begin{abstract}
Climate change has several adverse effects. One of these is 'sea level rise', which threatens two key requirements of statehood as stipulated by the declaratory theory of statehood and subsequently listed in the Montevideo Convention on the Rights and Duties of States. These are a defined territory and a permanent population. The focus of this paper is the implications of the rising sea level on the maritime boundaries, land territory and populations residing in small lowlying island nations. The central argument is that a rising sea level impugns the statehood of small low-lying island nations whose maritime boundaries are determined by ambulatory baselines. It further argues that a consistent rise in sea level may submerge small island nations, leading to their extinction. It concludes by proposing the principle of uti possidetis juris as a panacea to the retention of statehood of small island nations threatened by sea level rise.
\end{abstract}

Key Words: Sea level rise, statehood, Montevideo Convention and Uti Possidetis Juris

\section{Introduction}

The earth's climate has always been dynamic. ${ }^{1}$ Climate is the average of weather conditions derived from elements such as temperature, pressure and precipitation that are predominant in a certain place over a certain duration of

* The author holds a LL.B (Hons) (Magna cum Laude) from the University of Nairobi. The author would like to acknowledge, among others, the following Strathmore Law School Faculty members: Dr Francis Kariuki, Father Mark Muhoro, Mr Humphrey Sipalla, Mr Joe Kilonzo and the SLS 2019 Graduate Assistants for their enriching insights into this paper.

1 Borroughs W, Climate change: A multidisciplinary approach, Cambridge University Press, Cambridge, 2001, 1. 
time. ${ }^{2}$ It takes into account weather elements not only in their normal occurrences but also in instances of extreme incidents. ${ }^{3}$ We are accustomed to seasonal changes and fluctuations in the weather to the extent that we take climate change for granted. ${ }^{4}$ However, the acuteness and frequency of extreme incidents such as hurricanes and cyclones in recent history cannot be ignored anymore. ${ }^{5}$

Radical changes in climate began being experienced during the Industrial Revolution. ${ }^{6}$ Climate change is mainly attributed to anthropogenic factors. ${ }^{7}$ The leading anthropogenic factor is the increasing emission of Greenhouse Gases (GHGs) such as Carbon Dioxide $\left(\mathrm{CO}_{2}\right){ }^{8}$ The rapid increase in the use of fossil fuels drove up the levels of $\mathrm{CO}_{2}$ in the atmosphere. ${ }^{9}$ This was a result of industrialisation coupled up with the clamour for economic development by states..$^{10}$ It is estimated that GHGs atmospheric concentrations will have doubled the pre-industrial levels by $2050 .{ }^{11}$

Climate change has several adverse effects. First, it leads to global warming, which is so significant that the terms 'climate change' and 'global warming' are used interchangeably. ${ }^{12}$ The Intergovernmental Panel on Climate Change (IPCC) conservatively approximates that the increase in temperature will be ranging between 1.1 and 6.4 degrees Celsius by the year 2100. ${ }^{13}$ A large number of people find difficulty in grasping the magnitude of these temperature differences since

2 May R, The Britannica guide to climate change: An unbiased guide to the key issue of our age, Encyclopedia Britannica Inc, London, 2008, 40.

3 May R, The Britannica guide to climate change: An unbiased guide to the key issue of our age, 40.

4 Borroughs W, Climate change: A multidisciplinary approach, IX.

5 Leahy S, 'Why Cyclone Idai was so destructive’ National Geographic, 19 March 2019 - < https:// www.nationalgeographic.com/environment/2019/03/why-mozambique-cyclone-idai-was-sodestructive/> on 6 August 2019.

See also Livingston I, 'Historic Tropical Cyclone Kenneth crashes ashore in northern Mozambique, where devastating flooding is feared' The Washington Post, 25 April 2019 - < https://www. washingtonpost.com/weather/2019/04/25/historic-tropical-cyclone-kenneth-crashes-ashorenorthern-mozambique-where-devastating-flooding-is-feared/?noredirect=on> on 6 August 2019.

6 May R, The Britannica guide to climate change: An unbiased guide to the key issue of our age, VIII.

7 Anthropogenic factors are those factors that are induced by human activity. Nanda V and Pring G, International environmental law and policy for the $21^{1 t}$ century, $2^{\text {nd }} \mathrm{ed}$, Martinus Njihoff Publishers, Leiden, 2013, 395. Anthropogenic factors are those factors that are induced by human activity.

8 Watson R, Rodhe H, Oeschger $\mathrm{H}$ and Siegenthaler U, 'Greenhouse gases and aerosols' in Houghton J, Jenkins G and Ephraums J (eds), Climate Change: The IPCC scientific assessment, Cambridge University Press, Cambridge, 1990, 45.

9 May R, The Britannica guide to climate change: An unbiased guide to the key issue of our age, VIII.

10 Nanda V and Pring G, International environmental law and policy for the 21.t century, 399.

11 May R, The Britannica guide to climate change: An unbiased guide to the key issue of our age, VIII.

12 Louka E, International environmental law: Fairness, effectiveness and world order, Cambridge University Press, Cambridge, 2006, 356. They are used interchangeably mainly because global warming is the most conspicuous effect of climate change.

13 May R, The Britannica guide to climate change: An unbiased guide to the key issue of our age, VII. 
temperature differs from day to day. ${ }^{14}$ However, daily temperature fluctuations should be differentiated from changes in the global average temperature year after year. The numerous consequences of global warming such as desertification, droughts and floods affect different states and people disproportionately, more so, developing states. ${ }^{15}$

Africa, which contributes less than five percent of the global $\mathrm{CO}_{2}$ emissions, is the continent that is significantly affected by the effects of climate change. ${ }^{16}$ Statistics indicate that over 50 percent of the states most affected by the exposure to climate change are Sub-Saharan coastal African states such as Egypt, Equatorial Guinea and Guinea Bissau. ${ }^{17}$ Experts predict that Africa will experience an average temperature rise of up to 4 degrees celcius in this twentyfirst century. ${ }^{18}$ Africa's vulnerability to the consequences of climate change is a result of its high dependency on agriculture, which is thoroughly affected by fluctuations in the climate. ${ }^{19}$ This paper will focus on the effects of global warming on seas.

Global warming has several effects on seas. Of concern to this paper is the rise in sea level. This is through two mechanisms: thermal expansion of ocean and surface waters, commonly referred to as the steric effect and the melting of glaciers and ice-sheets around the world but mainly at the Poles. ${ }^{20}$ The Arctic region is experiencing a downward trajectory in its ice cover. ${ }^{21}$ In fact, ice at the Arctic is melting and disappearing at an accelerated rate. ${ }^{22}$ Consequently, the IPCC estimates a rise of approximately 0.38 to 0.59 metres in sea level by $2100 .^{23}$

14 Borroughs W, Climate change: A multidisciplinary approach, IX.

15 May R, The Britannica guide to climate change: An unbiased guide to the key issue of our age, IX.

16 African Union Commission, Agenda 2063: The Africa we want, 2015, 5.

17 United States Agency International Development, The intersection of global fragility and climate risks, 2018, 11-12.

18 African Union, African strategy on climate change (draft), 2014, 4.

19 Krampe $\mathrm{F}$ and Aminga V, 'The need for an African Union special envoy for climate change and security' Stockholm International Peace Research Institute, 7 February 2019 - < https://www.sipri. $\mathrm{org} /$ commentary/essay/2019/need-african-union-special-envoy-climate-change-and-security $>$ on 27 December 2019.

20 Caron D, 'Climate change and the oceans' in Scheiber H and Park J (eds), Regions, institutions and law of the sea: Studies in ocean governance, Martinus Nijhoff, Leiden, 2013, 530.

21 Potts T and Schofield C, 'Climate change and the evolving regional ocean governance in the Arctic' in Scheiber HN and Park JH (eds), Regions, institutions and law of the sea: Studies in ocean governance, Martinus Njihoff Publishers, 2013, Leiden, 437.

22 Chao J, 'China's emerging role in the Arctic' in Scheiber H and Park J (eds) Regions, institutions and law of the sea: Studies in ocean governance, Martinus Njihoff Publishers, Leiden, 2013, 467. In fact, between 1920 and 2005, it is estimated that the snow cover in the global North decreased by 1.5 square kilometres and the rate has henceforth increased.

23 Caron D, 'Climate change and the oceans', 531. 
African coastal states and islands will bear the brunt of the rise in sea level. The rise in sea level expected along Africa's coastlines is expected to be 10 percent higher than the global average rise. ${ }^{24}$ This rise is expected to be higher in southern Africa where a sea-level rise of 0.3 metres by 2050 has been projected. ${ }^{25}$ In fact, it is because of these effects that African island states joined their counterparts from other parts of the world to form the Alliance of Small Island States (AOSIS) ${ }^{26}$ The primary objective of AOSIS, since its inception, has remained climate change. ${ }^{27}$

The challenges facing the fight against climate change are briefly addressed since they lead to the propagation of its effects such as sea level rise, which is the core of this paper. Climate change has proven to be one of the most divisive and polarising issues facing the field of International Environmental Law since it evidently results from two competing interests. One is economic growth and development and the other is environmental conservation and preservation. ${ }^{28}$ Therefore, tackling climate change is viewed as tantamount to fighting capitalism and economic development. This is why the United Nations Framework Convention on Climate Change (UNFCCC) contains no enforcement mechanisms. ${ }^{29}$ Furthermore, UNFCCC's subsequent agreements such as the Paris Agreement have similarly attracted substantial opposition. ${ }^{30}$ These laws have failed to curb climate change since the majority of the largest emitters of GHGs are not interested in fulfilling their obligations under those laws. ${ }^{31}$

There is also a challenge experienced in collecting information despite having modern observation mechanisms and instruments. ${ }^{32}$ This creates a hiatus in the knowledge gained on climate change. Accurate facts, figures and parameters are required for a complete understanding of climate change and its effects. In the absence of these, there can be no coherent strategy by the global community

24 United Nations Economic Commission for Africa and Africa Policy Centre, Loss and Damage in Africa, 2014, 3.

25 United Nations Economic Commission for Africa and Africa Policy Centre, Loss and Damage in Africa, 2014, 12.

$26-<$ https://www.aosis.org/member-states/> on 27 December 2019.

27 - < https://www.aosis.org/about/> on 27 December 2019.

28 Nanda $\mathrm{V}$ and Pring G, International environmental law and policy for the $21^{15 t}$ century, 396.

29 Sands P, Principles of international environmental law, $2^{\text {nd }}$ ed, Cambridge University Press, Cambridge, 359. Sands describes it as a compromise package between two categories of states: those that wanted it to reflect specific targets and schedules for emissions reduction and those that just wanted a 'skeleton' that would serve as the foundation of future agreements.

30 Horner C and Marlo L, The legal and economic case against the Paris Climate Treaty: Cancelling US participation protects competitiveness and the constitution, Competitive Enterprise Institute, May 2017.

31 Nanda V and Pring G, International environmental law and policy for the 215t century, 396.

32 Borroughs W, Climate change: A multidisciplinary approach, 173. 
to regulate climate change effectively. Since its consequences are neither clear nor predictable, political leaders and diplomats face little incentives to address it. ${ }^{33}$

This paper assesses how the threats posed by the rising sea level necessitate the innovative application and modification of legal principles in order to ensure stability of the global order in two ways: ensuring certainty of maritime boundaries and safeguarding the statehood of the island nations affected. Part II of this paper narrows down to the effects of sea level rise on the statehood of small low-lying island nations. It does so by examining how sea level rise affects the features of statehood espoused by the declaratory theory of statehood and the Montevideo Convention on Rights and Duties of States. It analyses the interplay between the rising sea level, on one hand; and a defined territory and permanent population of member states of the AOSIS, on the other hand. Part III makes a case for the adoption of fixed baselines through modification of the principle of uti possidetis juris as an adaptation mechanism to preserve the statehood of the island states affected. Part IV highlights the implementation challenges that may face the recommendations offered and contains the conclusion of the paper.

\section{The Effect of a Rise in Sea Level on Statehood}

\section{i. The Concept of Statehood}

States are the primary subjects of international law. They enjoy an international legal personality to the fullest extent possible compared to other entities such as intergovernmental bodies. ${ }^{34}$ This paper's argument is pegged on the declaratory theory of statehood which treats the creation of states as a matter of fact and not law. ${ }^{35}$ Its proponents inter alia include Kunz, Moore and Briggs. ${ }^{36}$ It stipulates that an entity only acquires the status of a state when it meets certain characteristics of statehood. These include a permanent population, a defined territory, a government and a capacity to enter into relations with other states. ${ }^{37}$ This list is neither exhaustive nor immutable. ${ }^{38}$ However, it leads to the

\footnotetext{
Nanda V and Pring G, International environmental law and policy for the $21^{\text {st }}$ century, 425.

Aust A, Handbook of international law, $2^{\text {nd }}$ ed, Cambridge University Press, Cambridge, 2005, 16.

Yulin L, 'Statehood theory and China's Taiwan policy’ 2(1) Tsinghua Law Review, 2009, 4.

36 Prince J, 'The international legal implications of the November 1988 Palestinian declaration of statehood' 25(2) Stanford Journal of International Law, 1989, 700.

37 Yulin L, 'Statehood theory and China's Taiwan policy', 5.

38 Shaw M, International law, $6^{\text {th }}$ ed, Cambridge University Press, Cambridge, 2008, 198.

Shaw lists other relevant factors such as recognition and self-determination.
} 
conclusion that despite there being no universally-accepted definition of a state, the characteristics of a state are well-settled. ${ }^{39}$

These characteristics have been adopted by the Montevideo Convention on the Rights and Duties of States (hereinafter 'Montevideo Convention').40 This convention is a regional treaty among Central and South American states and has 16 state parties. ${ }^{41}$ However, it is widely recognised also as a restatement of customary international law with regard to the norms of statehood. ${ }^{42}$ These features are all pegged on the notion of territorial effectiveness. ${ }^{43}$

The other parallel theory of statehood, the constitutive theory, stipulates that entities only become states when they are recognised as such by alreadyexisting states. ${ }^{44}$ This theory maintains that it is only by recognition that an entity acquires an international legal personality and can therefore participate in international law. ${ }^{45}$ Recognition is referred to as the juristic baptism of an entity into statehood. ${ }^{46}$ However, the declaratory theory treats recognition simply as an act of goodwill that does not affect the legal status of an entity. The Montevideo Convention explicitly maintains that the creation and existence of a state is independent of recognition by other states. ${ }^{47}$

Numerous criticisms have been levelled against the constitutive theory. First, and most significant, is the fact that recognition by already-existing states is deemed to be an extremely subjective condition since it is based entirely on states' discretion. ${ }^{48}$ This is compounded in instances where some states recognise while others refuse to recognise an entity as a state. A problem emerges as to the number of recognitions that are required for an entity to be validly recognised as a state. This results in uncertainties with regard to which entities can universally

39 Hillier T, Sourcebook on public international law, Cavendish Publishing Limited, London, 1998, 181.

40 Article 1, Convention on the rights and duties of states, 26 December 1933, 165 LNTS 19.

41 Gagain M, 'Climate change, sea level rise and artificial islands: Saving the Maldive's statehood and maritime claims through the constitution of oceans' 23 (1) Colorado Journal of International Environmental Law and Policy, 2009, 89.

42 Gagain M, 'Climate change, sea level rise and artificial islands', 89.

43 Shaw, International law, 199.

44 Prince J, 'The international legal implications of the November 1988 Palestinian declaration of statehood', 681.

45 Wallace-Bruce N, 'Africa and international law: The emergence to statehood' 23 (4) The Journal of Modern African Studies, 1985, 594.

46 Crawford J, The creation of states in international law, Oxford University Press, New York, 1979, 14.

47 Article 3, Convention on the rights and duties of states.

48 Worster W, 'Law, politics and the conception of the state in state recognition theory' 27(1) Boston University International Law Journal, 2009, 120. 
be regarded as states. In addition to this, entities not recognised may still exercise state authority over their citizens. ${ }^{49}$

The declaratory theory is not free of defects. Its major criticism lies in instances where an entity has been recognised as a state without fulfilling the four conditions it espouses. ${ }^{50}$ For instance, the Democratic Republic of Congo was admitted into the United Nations (UN) in 1960 despite not having an effective government. ${ }^{51}$ This is further compounded by the hypocrisy showcased by states when they use different criteria for different states. ${ }^{52}$ Finally, states that have fulfilled the requirements stipulated by this theory do not acquire international rights and obligations in the international arena until they are recognised..$^{53}$

In the early twentieth century, the declaratory theory gained overwhelming approval by international law scholars and state practice due to its objective nature. ${ }^{54}$ Nonetheless, towards the end of the century, it lost its appeal to the UN collective recognition mechanism owing to the criticisms highlighted above. This collective recognition mechanism maintains that when an entity is admitted to the membership of the UN, in accordance with Article 4 of the Charter of the $\mathrm{UN}$, it becomes a state and as such its statehood cannot be subject to challenge. ${ }^{55}$ However, this mechanism is as subjective as the constitutive theory since it is discretionary and highly politicised. ${ }^{56}$

Despite the criticisms, this paper maintains its reliance on the declaratory theory of statehood based on numerous reasons. First, the concept of statehood is inseparable from territory. In fact, states have occasionally been described as territorial entities. ${ }^{57}$ Territory is, therefore, a precondition for any entity to be recognised as a state. For instance, attempts to recognise certain entities such as the Sovereign Military Order of St Joseph of Jerusalem, Rhodes and Malta as states have been futile. ${ }^{58}$ This is due to the fact that these entities have no

\footnotetext{
49 Worster W, 'Law, politics and the conception of the state in state recognition theory', 120.

50 Worster W, 'Law, politics and the conception of the state in state recognition theory', 119.

51 Yulin L, 'Statehood theory and China's Taiwan policy', 11.

52 Worster W, 'Law, politics and the conception of the state in state recognition theory', 119.

53 Worster W, 'Law, politics and the conception of the state in state recognition theory', 119.

54 Van der Vyer J, 'Statehood in international law' 5(1) Emory International Law Review, 1991, 12.

55 Yulin L, 'Statehood theory and China's Taiwan policy', 16.

56 Prince J, 'The international legal implications of the November 1988 Palestinian declaration of statehood', 702 .

57 Crawford, The creation of states in international law, 5.

58 This entity has a flag, a government and diplomatic missions globally. However, it is housed in the Magistral Palace in Rome, Italy - < http://www.orderofmalta.int/sovereign-order-of-malta/> on 27 December 2019.
} 
territory under their control. However, they have been accorded international legal personality, which is lower than statehood.

\section{ii. The Rise in Sea Levels and its Effect on Statehood}

The rise in sea level threatens the very core of the declaratory theory. The following sub-parts of this paper analyse how the rise in sea level may affect the territory of states and the populations residing in them. Without either of the two, this paper suggests that an entity cannot be a state so properly called. Finally, the relegation of the declaratory theory may imply that a state remains a state despite the non-existence of a defined territory and population. This may consequently trivialise the magnitude of the threat that coastal and lowlying island states face and so the measures the international community may undertake will not be sufficient.

It has been widely acknowledged that the rise in sea level is a reality. However, the rate and level of this rise is shrouded in uncertainty due to the interplay between the many factors involved. ${ }^{59}$ As indicated in the Introduction, the IPCC estimates a sea-level rise of between 0.38 to 0.59 metres by 2100 . However, there are contrary opinions that estimate that the sea will rise by not less than one metre by the year $2100 .{ }^{60}$ The rise of the sea by a couple of feet is sufficient to inundate many low-lying areas, coastal wetlands and islands. ${ }^{61} \mathrm{~A}$ rise of the sealevel by one metre is sufficient to flood Guyana, inundate thousands of acres in Louisiana and cause the relocation of New Orleans as well as submerge fifteen percent of Bangladesh. ${ }^{62}$ Low-lying island nations such as the Maldives, whose highest point is 3.5 metres, would suffer just as Bangladesh. ${ }^{63}$

\section{a. Rise in sea-level and defined territory}

Many low-lying islands are on the verge of being deleted from the world map since they are the biggest victims of the rise in sea level. ${ }^{64}$ The United

59 Schofield C, 'Shifting limits: Sea level rise and options to secure maritime jurisdictional claims' 3(4) Carbon and Climate Law Review, 2009, 405.

This is mainly as a result of the little knowledge amassed as to the rate of the melting of ice-sheets at the Poles.

${ }_{60}$ Caron D, 'Climate change and the oceans', 531

61 Caron D, 'Climate change and the oceans', 531

62 Caron D, 'When law makes climate change worse: Rethinking the law of baselines in light of a rising sea level'17(4) Ecology Law Quarterly, 1990, 627.

${ }_{63}$ Caron D, 'When law makes climate change worse: Rethinking the law of baselines in light of a rising sea level', 628.

${ }^{64}$ Sefrioui S, 'Adapting to sea level rise: A law of the sea perspective', 3. 
Nations Convention on Law of the Sea (UNCLOS) defines islands as natural areas of land engulfed by water but always above the water at high tide. ${ }^{65}$ An island that is capable of sustaining human habitation or economic life on its own legally generates a territorial sea, a contiguous zone, an exclusive economic zone (EEZ) as well as a continental shelf. ${ }^{66}$ Islands such as Kiribati, Tuvalu and the Maldives whose average height is between 1 to 1.5 metres are vulnerable to the rise in sea level. ${ }^{67}$ The reality of submersion of islands is best illustrated by the gradual sinking of Ghoramara Island in India due to several reasons, among them, the sea-level rise. ${ }^{68}$

When an island is submerged, the state loses its territory. It has no defined territory as required by the Montevideo Convention. The effective control of territory is the crux of any state since the central concept of territorial sovereignty is founded upon it. ${ }^{69}$ In the absence of a defined territory, a 'state' cannot exercise any sovereignty. The uncertainty caused by changing baselines on the maritime boundaries of a state is a threat to the statehood of a state. The International Court of Justice (ICJ) observes that it is not mandatory for the land boundaries of a state to be fully delimited. ${ }^{70}$ The absolute certainty of a state's boundaries is not a requirement for statehood. ${ }^{71}$ However, it is mandatory that the state maintains consistent and effective control of a substantial portion of the territory. Small low-lying islands are concerned by the fact that the rise in sea level affects their whole territory, either under partial or full submersion. This would translate into uncertainty over territory and, hence, loss of effective control and sovereignty over substantial portions of what previously amounted to their territory.

\section{b. Rise in sea level vis-à-vis permanent population}

This sub-part addresses the impact of sea-level rise on the second criterion of statehood that is a concern of this paper, which is a permanent population.

\footnotetext{
Article 121 (1), United Nations convention on law of the sea, 10 December 1982, 1833 UNTS 397.

Article 121 (3), United Nations convention on law of the sea.

67 Caron D, 'When law makes climate change worse: Rethinking the law of baselines in light of a rising sea level', 628.

68 Sengupta S, 'Sea rise in India buries islands and a way of life' New York Times, 11 April 2007 -<https://www.nytimes.com/2007/04/11/world/asia/11india.html> on 8 August 2019.

69 Malanczuk P, Akehurst's modern introduction to international law, $7^{\text {th }}$ ed, Routledge, London, 1997, 75. It creates exclusive competence on a state to undertake legal and factual measures within the territory.

70 North Sea continental shelf cases (Federal Republic of Germany/ Denmark: Federal Republic of Germany/ Netherlands), Judgment, ICJ Reports 1969, 46.

71 Malanczuk P, Akehurst's modern introduction to international law, 76.
} 
It is widely accepted that there is no stipulated minimum number of people that a state should have. ${ }^{72}$ Further, a population of such state does not have to be homogenous in terms of ethnicity, race, linguistics or religion. ${ }^{73}$ However, it has to be a settled population. ${ }^{74}$ It does not also need to hold the nationality of such state. ${ }^{75}$ The only condition is that their residence should be characterised by some degree of permanence. ${ }^{76}$

Sea level rise will inundate the coasts of many small low-lying islands and that will result in their flooding and submersion. ${ }^{77}$ This is catastrophic to the communities that live on the islands. It is estimated that about 60 million people live along the coasts of different countries. ${ }^{78}$ The rise in sea water, which is salty, will negatively interfere with the supply of fresh water in low-lying islands. ${ }^{79}$ This will affect the agricultural lands on these islands. ${ }^{80}$ Finally, this rise will result in more incidences of extreme events such as storms closer to the human habitations. ${ }^{81}$ These effects make these island states uninhabitable. Subsequently, the residents of these islands will be displaced and compelled to migrate from their current locations since this may be the only adaptive rational strategy that they will have. ${ }^{82}$

As a result of the effects highlighted in the previous paragraph, islands cannot support human existence on their own. Any island that loses its capacity to support human habitation and economic life on its own ceases to be an island and is in turn reclassified as a rock. ${ }^{83}$ Such rocks cannot generate maritime zones such as an EEZ or continental shelf. ${ }^{84}$ The United Kingdom (UK) voluntarily reclassified Rockall from island to rock status. ${ }^{85}$ They subsequently lost 60 thousand square nautical miles of a fishery zone. ${ }^{86}$ On a positive note,

\footnotetext{
Shaw M, International law, 199. Liechtenstein has a population of less than forty thousand people.

Aust A, Handbook of international law, 16.

Aust A, Handbook of international law, 16.

Hillier T, Sourcebook on public international law, 184.

Hillier T, Sourcebook on public international law, 184.

Caron D, 'Climate change and the oceans', 531.

Schofield C, 'Shifting limits: Sea level rise and options to secure maritime jurisdictional claims', 406.

May R, The Britannica guide to climate change: An unbiased guide to the key issue of our age, IX.

Schofield C, 'Holding back the waves: Sea level rise and maritime claims', 593.

Caron D, 'Climate change and the oceans', 531.

82 Vidas D, Freestone D and McAdam J, 'International law and sea level rise: The new ILA committee', $406<$ https://nsuworks.nova.edu/ilsajournal/vol21/iss2/9/> on 8 August 2019.

83 Article 121 (3), United Nations convention on law of the sea.

84 Article 121 (3), United Nations convention on law of the sea.

85 Charney J, 'Rocks that cannot sustain human habitation' 93 (4) The American Journal of International Law, $1999,876$.

86 Schofield C, 'Shifting limits: Sea level rise and options to secure maritime jurisdictional claims', 409. Currently, it merely generates a 12 nautical mile territorial sea.
} 
reclassification may be advantageous in the resolution of certain maritime disputes, particularly those concerning the Spratly Islands in the South China Sea. ${ }^{87}$ Reclassification of these islands to mere rocks would greatly reduce their ability to generate claims to extended maritime jurisdiction and, consequently, reduce the scope of the dispute. ${ }^{88}$

From the above scenarios it is beyond doubt that the notion of statehood according to the declaratory theory is under threat since two of its core characteristics are under attack. A literal interpretation of Article 1 of the Montevideo Convention indicates that all the four features of statehood must be fulfilled due to the use of the conjunction 'and'. This Article renders all the limbs conjunctive. ${ }^{89}$ Therefore, the declaratory theory is insufficient in addressing the statehood of states affected by climate change. The constitutive theory also falls short of accommodating the statehood of states affected by climate change.

\section{The Shortcomings of Ambulatory Baselines as a Solution: The Case for Fixed Baselines through Uti Possidetis Juris}

One of the notable achievements of UNCLOS is the establishment of a framework that determines the limits of claims to maritime jurisdiction by coastal states and islands. Baselines are the starting line for the measurement of maritime zones offshore as well as the demarcation between internal waters and the maritime zones. ${ }^{90}$ Internal waters are those on the landward side of the baseline while maritime zones are waters located on the seaward side of the baselines. ${ }^{91}$ Baselines are crucial in the determination of national claims to different maritime zones since the limits of the territorial sea, the contiguous zone, the EEZ and the continental shelf are measured from them. ${ }^{92}$ Baselines also play a critical role in delimitation of maritime zones between states with either opposite or adjacent coasts since they form the basis of the equidistance

\footnotetext{
Schofield C, 'Holding back the waves: Sea level rise and maritime claims', 598.

88 Rocks, as per Article 121 (3) of the LOSC Convention, do not have the capacity to generate an EEZ or a continental shelf. They are only capable of generating a 12 nautical mile territorial sea.

89 Raila Amolo Odinga and Another v Independent Electoral and Boundaries Commission and 2 others (2017) eKLR, para. 193.

90 Schofield C, 'Shifting limits: Sea level rise and options to secure maritime jurisdictional claims', 407.

91 Article 8, United Nations convention on law of the sea, 10 December 1982, 1833 UNTS 397.

92 Schofield C, 'Shifting limits: Sea level rise and options to secure maritime jurisdictional claims', 407.
} 
method of delimitation..$^{93}$ They are, therefore, credited with bringing about spatial certainty of the various maritime zones. ${ }^{94}$

There are two main types of baselines: normal baselines and straight baselines. ${ }^{95}$ The UNCLOS establishes normal baselines as the default baselines. ${ }^{96}$ They are the predominant type of baselines globally. ${ }^{97}$ Straight baselines are employed inter alia where the coastline of a state is deeply indented and are, therefore, the exception. ${ }^{98}$ Normal baselines are positioned at the low-water line, which is determined by the vertical datum along the coast of a state. ${ }^{99}$ These baselines can also be determined by low-tide elevations, which are land masses above water at low-tide but are submerged during high-tide. ${ }^{100}$

States have unilateral discretion to determine the low-water mark on which to draw their baselines since the UNCLOS is silent on the specific vertical datum for the low-water line. ${ }^{101}$ The baselines threatened by a rise in sea level are those that are founded upon the following geographic features: low-tide elevations, fringing reefs and islands. ${ }^{102}$ There are two schools of thoughts regarding the effects of a rise in sea level on the baselines. One school favours ambulatory baselines while the other supports fixed baselines.

93 Schofield C, 'Holding back the waves: Sea level rise and maritime claims' in Ruppel O, Roschmann $\mathrm{C}$ and Ruppel-Schlichting K (eds), Climate change: International law and global governance, Nomos Verlagsgesellschaft mbH and Co. KG, Baden-Baden, 2013, 596.

94 Schofield C, 'Departures from the Coast: Trends in the application of territorial seas baselines under the law of the sea convention' 27(4) International Journal of Marine and Coastal Law, 2012, 723. Schofield C, 'Shifting limits: Sea level rise and options to secure maritime jurisdictional claims', 407.

96 Schofield C, 'Shifting limits: Sea level rise and options to secure maritime jurisdictional claims', 407.

${ }_{97}$ Schofield C, 'Shifting limits: Sea level rise and options to secure maritime jurisdictional claims', 407.

98 Article 7, United Nations convention on law of the sea.

See also Anglo-Nowergian Fisheries Case (United Kingdom v Norway), Judgment, ICJ Reports 1951, 33. The International Court of Justice (ICJ) upheld the use of straight baselines by Norway whose Northern Coast is deeply indented.

See also Maritime Delimitation and Territorial Questions between Qatar and Babrain (Qatarv Babrain) (Merits), Judgment, ICJ Reports 1994, 2001, 221. The court held that straight baselines which are an exception to the general rule of determining baselines must be applied restrictively.

99 Schofield C, 'Shifting limits: Sea level rise and options to secure maritime jurisdictional claims', 408.

100 Article 13, United Nations convention on law of the sea.

101 Caron D, 'When law makes climate change worse: Rethinking the law of baselines in light of a rising sea level', 631.

This position has not been subject of adjudication before any international court or tribunal.

See also Schofield, 'Shifting limits: Sea level rise and options to secure maritime jurisdictional claims', 408.

102 Caron D, 'Climate change and the oceans', 533.

Article 13, United Nations convention on law of the sea, defines low-tide elevations as natural areas of land above water at low tide but submerged at high tide. 


\section{i. Ambulatory Baselines}

When features from which baselines are founded upon disappear or are submerged, the baselines must move, and any maritime boundary that has been generated from it must be redrawn from a new baseline. ${ }^{103}$ Therefore, the baseline also shifts accordingly. Consequently, this leads to an advancement or recession of the maritime boundaries. ${ }^{104}$ The UNCLOS does not expressly provide for the shifting nature of baselines. However, David Caron avers that it is implicitly provided for in Article 7(2) which states that straight baselines may be changed by coastal states in accordance with the UNCLOS, and so he concludes that the outer demarcations of the territorial sea, contiguous zone and the EEZ are shifting in nature. ${ }^{105}$ The ICJ implicitly upheld this position when it declined to consider a certain point along the mouth of River Coco as the basis for the Honduran baseline since it no longer reflected the physical geographic reality. ${ }^{106}$

The higher the rise in sea level, the larger the shift in the baselines and, consequently, the greater the uncertainty with regard to maritime boundaries. ${ }^{107}$ The implications of this legal uncertainty call for renegotiation of maritime boundary agreements to ensure that they correspond with current geographic realities. ${ }^{108}$ History demonstrates that uncertainty and modification of boundaries is one of the recipes for inter-state conflicts. ${ }^{109}$ These conflicts will be further enhanced by the fact that any change in maritime boundaries, especially between opposite and adjacent states, will affect the rights and duties of these states

103 Sefrioui S, 'Adapting to sea level rise: A law of the sea perspective' in Andreone G (ed), The future of law of the sea: Bridging gaps between national, individual and common interests, Springer Open, New York, 2017, 15.

This ambulatory nature of baselines is manifested in two ways: when the feature upon which the boundary is based is submerged, the baseline has to be redrawn and the previous maritime boundary is redrawn based on the new position of the baseline.

104 Caron D, 'Climate change and the oceans', 532.

105 Caron D, 'When law makes climate change worse: Rethinking the law of baselines in light of a rising sea level', 635.

This is based on the argument that Article 76 (4) of the LOSC expressly and permanently fixes the outer limit of the Continental Shelf while it is silent on the outer limits of the other maritime zones.

106 Case concerning territorial and maritime dispute between Nicaragua and Honduras in the Caribbean Sea (Nicaragua $v$ Honduras), Judgment, ICJ Reports 2007, 278.

107 Caron D, 'When law makes climate change worse: Rethinking the law of baselines in light of a rising sea level', 645 .

108 Sefrioui S, 'Adapting to sea level rise: A law of the sea perspective', 15.

109 Caron D, 'When law makes climate change worse: Rethinking the law of baselines in light of a rising sea level', 645.

For instance the current dispute between Somalia and Kenya with regards to the maritime boundary between the two states - <https://www.icj-cij.org/en/case/161> on 28 December 2019. 
particularly with regard to the exploitation of valuable ocean resources. ${ }^{110}$ Any doubt as to the ownership of living and non-living resources will form grounds for inter-state disputes.

The second effect is the alteration of the legal status of maritime zones. ${ }^{111}$ This means that the legal status of the maritime zones effectively changes. For instance, part of the territorial sea becomes internal waters, part of the contiguous zone becomes part of the territorial sea while part of the EEZ becomes the high seas. ${ }^{12}$ This creates a complex web of confusion and mayhem in the legal order governing the sea and particularly activities such as innocent passage, fishing rights and the freedom of navigation. Failure to reflect this shift of the baseline on large-scale or navigational charts would act as an impediment to the freedom of navigation. ${ }^{113}$ This arises from the ambulatory nature of baselines, which, in effect, means that maritime zones derived from the baselines are shifting as well.

Thirdly, states whose baselines and subsequent maritime zones are pegged on geographic features that are threatened by the rise in sea level may set aside huge sums of money and resources to maintain these features artificially. ${ }^{114}$ This is meant to protect the baselines, which, consequently, leads to the maintenance of the valuable maritime zones derived from such baseline. These valuable zones contain key ocean-based resources such as fisheries and minerals, which states want to retain under their sovereignty. ${ }^{115}$ The costs of this are very high. For instance, Japan committed 240 million US dollars to protect Okinotorishima (two rocks) from high tide. ${ }^{116}$ The country spent this money constructing blocks of steel and concrete around Okinotorishima. ${ }^{117}$

\section{ii. Fixed Baselines}

Fixed baselines are baselines which, once determined and cartographically reflected on large-scale charts, do not change until these charts are redrafted

Sefrioui S, 'Adapting to sea level rise: A law of the sea perspective', 15.

Sefrioui S, 'Adapting to sea level rise: A law of the sea perspective', 11.

Sefrioui S, 'Adapting to sea level rise: A law of the sea perspective', 10.

Sefrioui S, 'Adapting to sea level rise: A law of the sea perspective', 16.

4 Sefrioui S, 'Adapting to sea level rise: A law of the sea perspective', 15-16.

115 Caron D, 'When law makes climate change worse: Rethinking the law of baselines in light of a rising sea level', 639.

116 Caron D, 'When law makes climate change worse: Rethinking the law of baselines in light of a rising sea level', 639.

117 Caron D, 'When law makes climate change worse: Rethinking the law of baselines in light of a rising sea level', 640 . 
irrespective of the physical reality. ${ }^{118}$ States are obliged to show the position of their baselines on large-scale charts or alternatively provide geographical coordinates. ${ }^{119}$ These charts or coordinates must be publicised and deposited with the UN Secretary General. ${ }^{120}$ The implication of fixed baselines is fixed maritime zones. The UNCLOS arguably fixes the outer limit of the continental shelf. ${ }^{121}$ This is because of the amount of investment made by states in the continental shelf. Furthermore, demarcation of the continental shelf requires huge amounts of resources due to its nature and any resultant survey caused by the shift in the physical baseline would just be as costly. ${ }^{122}$

Fixed baselines, just like fixed land frontiers, bring about certainty over boundaries. ${ }^{123}$ This clarity ensures that the boundaries of a state, whether land or maritime, are easily identifiable. Consequently, the authority entitled to exercise sovereignty or other rights in a zone is known. A boundary system that is readily ascertainable brings about stability in the expectations of all the parties involved. ${ }^{124}$ The ICJ emphasises that one of the core objects of boundaries is to attain finality and stability. ${ }^{125}$ This stability brings about peaceful relationships between states and the avoidance of unnecessary conflicts. ${ }^{126}$ Proponents of fixed baselines argue that baselines should not advance or recede as a result of geographic realities such as sea level rise. ${ }^{127}$

Fixed maritime boundaries will serve to boost states' adaptation mechanisms to climate change. Rather than spending great resources to try to preserve their baselines, states may divert these resources to sustainable methods of responding to climate change. ${ }^{128}$ Low-lying island nations under threat from climate change

118 Caron D, 'Climate change and the oceans', 532.

119 Article 16 (1), United Nations convention on law of the sea.

120 Article 16 (2), United Nations convention on law of the sea.

121 Article 76 (4), United Nations convention on law of the sea.

122 Caron D, 'When law makes climate change worse: Rethinking the law of baselines in light of a rising sea level', 635.

123 Caron D, 'When law makes climate change worse: Rethinking the law of baselines in light of a rising sea level', 642.

124 Caron D, 'When law makes climate change worse: Rethinking the law of baselines in light of a rising sea level', 644.

125 Case Concerning the Temple of Preah Vihear (Cambodia v Thailand), Judgment, ICJ Reports 1962, 34.

126 In the Matter of the Bay of Bengal Maritime Boundary Arbitration between the People's Republic of Bangladesh and the Republic of India, Award,2014, para. 216.

127 Sefrioui S, 'Adapting to sea level rise: A law of the sea perspective', 18.

This preserves certainty and hence ensures that the ownership of various living and non-living resources is not in doubt. In addition, every player would be aware of their rights and duties in various maritime zones and hence activities such as navigation and fishing would not be shrouded in uncertainty.

128 Caron D, 'When law makes climate change worse: Rethinking the law of baselines in light of a rising sea level', 650 . 
would be better off appropriating funds to save their citizens from the negative effects of climate change than spending substantial amounts of resources to preserve their baselines. For instance, the Maldives spent resources constructing an artificial island, Hulhumale Island, as an adaptation measure to sea level rise. ${ }^{129}$ Hulhumale Island has been christened the 'modern Noah's Ark." ${ }^{130}$ Therefore, the concept of fixed baselines would be instrumental in promoting this.

Fixed baselines have gained favour under international law. The Vienna Convention on the Law of Treaties (VCLT) allows states to terminate or withdraw from a treaty or agreement due to the concept of fundamental change in circumstance. ${ }^{131}$ However, Article 62(2) of the VCLT provides that fundamental change in circumstance cannot be grounds for terminating a treaty or agreement that establishes a boundary. The sanctity of boundary agreements is well protected under international law. The ICJ has authoritatively upheld this provision, stating that, for the sake of stability, certainty and permanence, agreements on boundaries fall within the exception in Article 62(2) of the VCLT. ${ }^{132}$

\section{iii. A Case for Uti Possidetis Juris}

Africa's ocean territory is thrice the size of its land mass. ${ }^{133}$ It is therefore prudent that Africa is at the forefront in climate change mitigation and adaptation. Aspiration 1 of Agenda 2063 maintains that Africa will strive to have a unified stand on climate change. ${ }^{134}$ Agenda 2063 mandates African states to implement climate change adaptation mechanisms urgently. However, the Draft African Union Strategy on Climate Change does not incorporate any adaptation mechanisms that African states can undertake with regard to the rise in sea level. ${ }^{135}$ This is a result of the technical nature of climate change. Literature indicates that Africa lacks both the technological and knowledge systems to adequately address the effects of sea level rise. ${ }^{136}$ This paper disputes this allegation as unfounded by providing a recommendation that has been widely used in the African context as one of the mechanisms for sea level rise adaptation.

\footnotetext{
Gagain M, 'Climate change, sea level rise and artificial islands', 80.

Gagain M, 'Climate change, sea level rise and artificial islands', 80.

31 Article 62 (1), Vienna convention on the law of treaties, 23 May 1969, 1155 UNTS 331.

132 Aegean Sea Continental Shelf Case (Greece v Turkey), Judgment, ICJ Reports 1978, 85.

133 African Union Commission, Agenda 2063: The Africa we want, 5.

134 African Union Commission, Agenda 2063: The Africa we want, 6.

135 African Union, African strategy on climate change (draft), 48.

136 Addaney M, 'Climate change adaptation law and policy in the African Union: Creating legal pathways for adaptation’ Adaptation Futures at University of Cape Town, South Africa, December 2018, 4.
} 
This paper recommends that the international community sticks with the current baselines as they are. It proposes the adoption of fixed baselines and their consequent maritime zones as opposed to ambulatory baselines. Unlike Caron who proposes the use of fixed baselines through a United Nations General Assembly (UNGA) resolution or an amendment to UNCLOS, this paper proposes that fixed baselines can be effectively achieved through the adoption of the principle of uti possidetis juris in the governance of ocean and maritime frontiers. This is because resolutions by the UNGA are not legally binding but merely recommendatory. ${ }^{137}$ Furthermore, scholars suggest that due to the delicate balance of various interests in UNCLOS, any amendment may result in its collapse -

'...but the crucial matter is that in the end product, the Convention had to balance the various economic, political, security and social interests delicately. And this is what makes UNCLOS III unique in the history of multilateral treaty negotiation. Almost each and every provision is so delicately balanced against each other that most observers believe that reactivating one or two issues may in fact lead to a chain reaction that may reduce the monumental draft convention to rubble'. ${ }^{138}$

Uti possidetis juris has its origin in the Roman Empire. ${ }^{139}$ Uti possidetis juris stipulates that newly independent states maintain their administrative colonial boundaries. ${ }^{140}$ This principle was widely used during the decolonisation period in Africa. It was adopted in Resolution 16(1) of the Organisation of African Unity (OAU). ${ }^{141}$ Its consequence was to turn colonial administrative boundaries into international frontiers. It was applied by the ICJ in the frontier dispute between Burkina Faso and the Republic of Mali. ${ }^{142}$

This principle does not apply retrospectively but rather from that moment onwards. The ICJ has fondly referred to this as the photograph of the existing territorial situation. ${ }^{143}$ Uti possidetis juris literally freezes the territorial title. Attempts by African states to deviate from uti possidetis juris and rely on claims such as ethnic or historical entitlements have been futile. ${ }^{144}$ Aside from its use

\footnotetext{
Shaw M, International law, 114.

38 Professor Charles Okidi Odidi, November 1982.

139 Lalonde S, Determining boundaries in a conflicted world: The role of uti possidetis, McGill-Queen's University Press, Montreal, 2002, 3.

140 Shaw M, 'The heritage of states: The principle of uti possidetis juris today' 67(1) British Yearbook of International Law, 1996, 97.

141 Shaw M, 'The heritage of states: The principle of uti possidetis juris today', 103.

142 Case concerning the frontier dispute (Burkina Faso/ Republic of Mali), Judgment, ICJ Reports 1986, para. 30.

143 Case concerning the frontier dispute (Burkina Faso/ Republic of Mali), para. 30.

144 Hasani E, 'Uti possidetis juris: From Rome to Kosovo' 27 Fletcher Forum of World Affairs 2, 2003, 88.
} 
in the colonisation arena, it was relied upon during the disintegration of former communist federations such as Yugoslavia and the Soviet Union. ${ }^{145}$ This paper, therefore, calls for its further modification to save the statehood of islands whose boundaries are threatened by climate change. The proposed modification lies in the fact that the territorial boundaries that this principle seeks to save are those that currently appear on the large-scale charts deposited by states to the UN in accordance with Article 16 of the UNCLOS, rather than the independence borders.

Uti possidetis juris brings about certainty, predictability and stability of boundaries. It also serves to prevent conflicts over boundaries. Uti possidetis juris has been crucial in solving boundaries issues during decolonisation and state succession. ${ }^{146}$ This paper proposes the incorporation of uti possidetis juris as an adaptation mechanism to the rise in sea level. It hails uti possidetis juris as the panacea for retaining the statehood of islands that have not been fully submerged but which may have lost their capacity to support human populations on their own. ${ }^{147}$ These are islands that may be in a position to cater for human population but with assistance from other states or territories. It recommends that uti possidetis juris be applied to maintain the maritime boundaries as they currently are according to the large-scale charts deposited with the UN Secretary General. These charts reflect the position of the baselines and the maritime boundaries irrespective of the geographical reality. ${ }^{148}$

\section{Implementation Challenges and Conclusion}

\section{i. Challenges}

The first challenge is conceptual. Proponents of the constitutive theory of statehood may find it difficult to accept this recommendation since they take into account recognition as the only criterion for statehood. They may argue that since we have had instances where governments have been recognised while in exile, states can also be recognised as such. International law does not cater for the extinction of statehood through means other than state succession. This

\footnotetext{
Hasani E, 'Uti possidetis juris: From Rome to Kosovo' 85.

146 Lalonde S, Determining boundaries in a conflicted world: The role of uti possidetis, McGill-Queen's University Press, Montreal, 2002, 3.

147 This recommendation is only viable for island nations that are not fully submerged.

148 Sefrioui S, 'Adapting to sea level rise: A law of the sea perspective', 13.
} 
leads us to the current detriment, which is 'what happens to a state that no longer has a defined territory and/or a permanent population?' This question places scholars and practitioners in an unprecedented imbroglio. Constitutive theorists may accord such 'states' some sui generis international legal personality such as that accorded to the Sovereign Military Order of St Joseph of Jerusalem, Rhodes and Malta.

Secondly, this recommendation may be criticised on the grounds that the retained boundaries will not reflect the actual physical geographical reality. However, if all states decide to follow this approach it will no longer be an issue. A problem will only arise where states foresee that they will benefit from the sea level rise and oppose this recommendation. One of the benefits may be an increase in the spatial limits of their maritime zones. This will result from the fact that sea level rise does not affect all states homogenously.

\section{ii. Conclusion}

The rising sea level threatens the territory, populations and therefore the existence of small low-lying islands globally. These two criteria are part of the core requirements for the attainment of statehood according to the declaratory theory. In terms of territory, the rising sea level challenges both the maritime zones and land territory of these islands. The land territory is being inundated and is slowly sinking under the sea. These islands are facing a threat similar to the mythical Atlantis. An island state that is fully submerged loses its territory. There is no precedent for this scenario under international law. It is, therefore, yet to be seen whether statehood ends once a state has no more territory. People who live on these threatened islands will have no option but to migrate as the sea level rises to what have been their homes. A state with no permanent population may lose its statehood.

Uti possidetis juris has previously been used to transform colonial administrative boundaries in Africa to the current international land borders. It can be transposed to protect maritime boundaries of islands under threat from sea level rise but which have not been fully submerged. These islands may still be in a position to support human population but not necessarily on their own. This principle may serve as an adaptive measure to protect the statehood of these islands. It will solve the territorial threat since it will serve to maintain the fixed boundaries of these islands irrespective of the physical reality resulting from sea-level rise. This will bring about stability of boundaries which in turn leads to defined territories. 
